\title{
THE
}

UNIVERSITY

University of Rhode Island

OF RHODE ISLAND

DigitalCommons@URI

$11-27-2013$

\section{Learning to Engage: How Positive Attitudes about the News, Media Literacy, and Video Production Contribute to Adolescent Civic Engagement}

\author{
Renee Hobbs \\ University of Rhode Island, hobbs@uri.edu \\ Katie Donnelly \\ University of Rhode Island, katie_donnelly@etal.uri.edu \\ Jonathan Friesem \\ University of Rhode Island \\ Mary Moen \\ Honiversitty of Rhodgitsland,mark_moen@uriediwalcommons.uri.edu/com_facpubs
}

The University of Rhode Island Faculty have made this article openly available.

Please let us know how Open Access to this research benefits you.

This is a pre-publication author manuscript of the final, published article.

Terms of Use

This article is made available under the terms and conditions applicable towards Open Access

Policy Articles, as set forth in our Terms of Use.

\section{Citation/Publisher Attribution}

Renee Hobbs, Katie Donnelly, Jonathan Friesem \& Mary Moen (2013) Learning to engage: how positive attitudes about the news, media literacy, and video production contribute to adolescent civic engagement, Educational Media International, 50:4, 231-246, DOI: 10.1080/09523987.2013.862364

Available at: http://dx.doi.org/10.1080/09523987.2013.862364

This Article is brought to you for free and open access by the Communication Studies at DigitalCommons@URI. It has been accepted for inclusion in Communication Studies Faculty Publications by an authorized administrator of DigitalCommons@URI. For more information, please contact digitalcommons-group@uri.edu. 


\section{Learning to Engage:}

How Positive Attitudes about the News, Media Literacy, and Video Production Contribute to Adolescent Civic Engagement

By Renee Hobbs, Katie Donnelly, Jonathan Friesem, and Mary Moen

Accepted for publication in Educational Media International

Charalambos Vrasidas, Editor

CARDET-UNIC, PO Box 20813

Nicosia 1664, Nicosia, Cyprus

Email:pambos@cardet.org

1 


\title{
Learning to Engage: \\ How Positive Attitudes about the News, Media Literacy, and Video Production Contribute to Adolescent Civic Engagement
}

\begin{abstract}
Many students enroll in video production courses in high school as part of a vocational, career, or technical program. While there has been an explosion of scholarly work in digital literacy in informal settings, less is known about how digital and media literacy competencies are developed through school-based video production courses. This study explores the relationship between civic engagement and the various multimedia instructional practices used in a high school video production course with a single-school convenience sample and an ethnically diverse population of students. Findings reveal that the best predictors of the intent to participate in civic engagement are having positive attitudes about news, current events, reporting, and journalism. Media literacy attitudes and a range of in-classroom learning experiences with video production are also associated with civic engagement.
\end{abstract}

Keywords: media literacy, secondary education, news literacy, civic engagement, curriculum, learning, outcomes, measures, media production, youth media 
The inclusion of digital media production learning experiences in the context of American public education has been recommended for decades by media scholars and educators as a way to advance adolescent development. Scholars suggest that these programs support literacy (Hobbs, 2011), civic engagement (Kahne, Feezel \& Lee, 2011), and an interest in news and current events (Mihailidis, 2008). But what do we know about whether media production experiences, implemented in high schools, actually result in such outcomes? English and social studies teachers have been experimenting with the use of multimedia video composition and the use of nonprint media since the 1970s as a means to support the needs of all learners and to address the crisis of relevance that develops as students question the relationship between the knowledge and skills that are valued in the classroom and what is valued in contemporary society (Masterman, 1985). Many of today's students see no connection between the classroom and the culture, and these attitudes have a negative impact on motivation. For example, only $28 \%$ of graduating high school seniors believe that what they do in classrooms is meaningful and useful to their lives or futures (Bachman, Johnston, \& O’Malley, 2008), and this proportion has been decreasing for many years. 
Fortunately, new approaches to engaging learners are building upon some of the changing models of citizenship that are the result of the shift from a print to a digital culture. Indeed, the conceptualizations of the dutiful citizen, one who simply votes in elections, is being replaced by the actualizing citizen, whose engagement in the public sphere is connected to person and social identity (Bennett, Wells \& Freelon, 2011). Citizens are expected to be both "readers" and "writers," participating in discussion and debate that advances action. New forms of civic learning include a focus on producing information that is created and shared by peers, learning to use self-produced and selfdistributed digital and social media, and participating in peer-centered special interest groups. These creative practices of civic participation are dependent upon an appreciation of the role of media in democratic societies. As Banks (2001, p. 9) explains, "To become thoughtful citizen actors (we) must understand the ways in which knowledge is constructed and how knowledge production is related to location of knowledge producers in the social, political and economic contexts of society."

When implemented in either school or informal learning settings, digital and media literacy (including both media analysis and media composition activities) enables students to reflect on their uses of media and technology, analyze and evaluate media messages, and create works that are "dynamic, interactive, generative, exploratory, visual and collaborative" (Conference on English Education, 2005, p. 1). The National Council for the Social Studies position statement (2009) on media literacy education notes that media literacy entails "broadening the definition of what is considered acceptable text to include multiple ways people read, write, view, and create information and messages" (p. 1). In this view, legitimate texts include popular culture, advertising, photographs, maps, 
text messages, movies, video games, and Internet web sites, as well as print. Media literacy also involves multimedia production as students learn to create messages with different media and technology. In composing with image, language and sound, students must consider audience, purpose, genre, form, and context. By creating presentations, Internet blogs, videos, podcasts and other forms of expression and communication, students gain confidence in using their voices to explore the relationship between information, knowledge, and power.

A variety of English education organizations, including the National Council of Teachers of English (NCTE) and the Conference on English Education (CEE) have also recognized the need to include both the critical analysis of nonprint texts and multimodal creative production projects into the secondary English curriculum, and the Common Core standards seems to support media literacy when it states, "To be ready for college, workforce training, and life in a technological society, students need the ability to gather, comprehend, evaluate, synthesize, and report on information and ideas, to conduct original research in order to answer questions or solve problems, and to analyze and create a high volume and extensive range of print and nonprint texts in media forms old and new" (21 ${ }^{\text {st }}$ Century Information Fluency, 2012).

In the informal learning sector, digital storytelling activities provide opportunities for young people to discover the creative and collaborative accomplishments that result from the experience of gaining a sense of voice and agency through digital media. These programs often make use of an adult mentor who leads youth through a step-by-step process of first creating a story and then converting it to a storyboard, shooting images, learning video editing software, writing and performing scripts, and selecting music to 
accompany their final productions. Productions are seen to provide a means by which youth can exemplify and personify the self in direct relation to their peers and community members (Hull \& James, 2007). Similarly, the MacArthur Foundation has supported research in digital learning in an informal setting, and there has been an explosion of evidence showing the increased levels of motivation and engagement that result from connected learning, where students pursue their interests in "a socially meaningful and knowledge rich economy of engaging participation, self-expression and recognition" (Ito and Salen, 2012, p. 1).

Little is known, however, about how multimedia production experiences in high school have impact on student learning. There is only a slender body of research on video production courses in American high schools, even though many high schools have offered courses in video production since the 1970s when schools built TV studios and equipped them with the latest in audio-visual educational technology. Today, about $50 \%$ of American high schools have video production courses, generally as part of a career and technology education sequence (U.S. Department of Education, 2010). For example, the Audio Video Production and Animation program at Anderson High School in Austin, Texas offers a program that is designed to provide students with the opportunity to explore careers in the film and animation industries. Courses emphasize cinema/animation history, media analysis, principles of digital photography, and filmmaking and animation practices. Students work in collaborative groups in order to write, shoot, and edit projects using professional editing software. Typically, students are offered a sequence consisting of an introductory course which includes a mix of both media analysis and video production activities, followed by a series of more advanced 
production courses, including courses in animation, video game design, news broadcasting, or film. In such courses, students will typically use software tools such as Final Cut Pro 7, GarageBand and Soundtrack Pro, and Adobe Photoshop CS6. But not every student will have identical learning experiences in a video production course, because these courses generally involve students in active peer collaboration, engaged in a variety of different types of projects that involve a wide variety of knowledge and skills. For this reason, it is important to carefully document the kinds of skills that are activated in video production learning experiences and to consider how these skills intersect with attitudes and behaviors that contribute to civic engagement.

This study explores the relationship between civic engagement and some of the various multimedia instructional practices used in high school video production courses. In pilot-testing a battery of measures for a larger study of a multi-school news literacy program sponsored by by PBS Student Reporting Labs and developed by MacNeil/Lehrer Productions, we created and validated measures of adolescent news media usage, video production skills, civic engagement, media literacy competencies, vocational interest in media careers, and attitudes about the media, including media cynicism, perception of media self-interest, and perception of the positive intent and value of the news. Using a single-school convenience sample, this study provides evidence that multimedia production experiences contribute to democratic attitudes. Attitudes towards news, media literacy competencies, and in-class video production experiences predict students' own anticipated civic engagement.

\section{LITERATURE REVIEW}




\section{Video Production in High School}

In attempting to document the composition practices used in high school media production courses, researchers generally use case studies, teacher action research, participant-observation and interviewing — not survey research — to understand how and what students learned in their use of video. Multimedia production experiences in high school may support the development of a variety of competencies, including creativity, collaboration, communication and critical thinking (Goble, 2012). Researchers have found that high school video production courses emphasize a mix of technical and nontechnical skills (Hocutt, Stanford, Wright \& Raines, 2001) and that high school video production activities facilitate connections to content, enhance student motivation and engagement, support the use of alternative assessment, and cultivate shifts in teacher identity (Norton \& Hathaway, 2010). Qualitative evidence shows that what distinguishes successful high school programs is the development of a classroom culture that is maintained in part through unequal distribution of student expertise which gives rise to a small group of students with strong technical and social skills. The production process enables students to develop specializations (e.g., cinematography, video editing, oncamera performance, sound design, etc.) as they learn to work collaboratively on projects. In this instructional model, informal learning via peer leadership creates meaningful incentives for student participation (Miller, 2010; Reilly, 1994).

However, students may be differentially impacted by media literacy education. Some quantitative research has shown that the design and organizational structure of digital and media literacy programs in high school has a significant impact on the impact of student learning (Martens \& Hobbs, in press). Although media literacy is becoming 
more normative in North America and a variety of assessment instruments are emerging (Arke \& Primack, 2009), even when substantive investment is made in providing teachers with opportunities to implement digital and media literacy into English or social studies education, there has been only a modest amount of advancement nationwide. The traditional high school context, with its fixed time schedules and rigid course sequence, can tend to isolate digital and media literacy practices as stand-alone electives taught by specialist "enthusiast" teachers (Hobbs, 2011). Some experts believe that media literacy is more likely to develop in out-of-school contexts where students can experiment freely with digital media and "connected learning" can thrive (Ito and Salen, 2012).

For these reasons, there are relatively few empirical research studies that examine the impact of video production learning experiences on the academic, social, or emotional development of adolescents. Media production courses, at the high school level, are nearly always presented as electives, not as required courses. Scholastic journalism programs have been active for more than 40 years and are often positioned as contributing to support students' interest in media vocations (Hallam, 2010). Multimedia production courses may also be used in some high schools to support the needs of noncollege bound youth who are generally tracked into vocational education programs as a result of poor test scores and low grades in academic classes. Typically, these courses are offered in Career and Vocational Education departments, which are not well-aligned with the scope and sequence of academic courses in English or Social Studies. Across the country, there is considerable variation in how high school video production courses are positioned. In some high schools, the video production course attracts college-bound youth who are attracted to the creativity, self-expression, and empowerment offered by 
becoming a part of the school news or video production team (Goble, 2012). In some states, students may receive English or Social Studies credit for taking a video production course; however, in other school districts, this is expressly prohibited. The elective nature of these courses poses a challenge to researchers. But more importantly, the substantial differences that may exist from student to student and district to district reflect a larger concern about how "cafeteria models" of education which enable students to select their own courses may or may not ensure educational equity and quality for all learners (Murphy, Hull \& Walker, 1987).

For these reasons, we wanted to understand the development of multimedia production skills among high school students in relation to their in-class learning activities and their pre-professional interests in media careers. We ask:

RQ1. What is the range of knowledge, skills, attitudes and competencies that are learned in a high school video production course?

RQ2. Is active participation in video production courses associated with preprofessional vocational interest in media careers?

\section{Media Literacy and Civic Engagement}

Social studies educators recognize the value of digital media literacy as an essential life skill of the 21 st century world "where the majority of information people receive comes less often from print sources and more typically from highly constructed visual images, complex sound arrangements, and multiple media formats" (National Council for the Social Studies, 2009, p. 1). New skills are needed for accessing, analyzing, evaluating, creating, and distributing messages within a digital, global, and democratic society. When students are aware of the importance of media messages in 
public life and have the ability to both critically question and create messages using new media and technology, students are empowered to become active participants in the process of democracy. If this is true, we would expect that students completing a video production course would be active, self-motivated learners and engaged civic actors.

A number of scholars have examined the relationship between digital media literacy education and civic engagement among young people. Martens and Hobbs (in press) surveyed 400 high school students in Maryland in order to assess the relationships among media literacy education, frequency of Internet use, information-gathering motivations, media literacy competencies, and civic engagement. Their results showed that participation in a media literacy program was positively related to informationseeking motives, media knowledge, and news analysis skills, which independently contributed to students' intent to engage in forms of civic engagement such as volunteering, voting and expressing political opinions in a public forum.

In order to define the widest range of potentially useful forms of civic engagement, researchers have sought to evaluate adolescents' civic knowledge and behaviors, media consumption and perceptions, attitudes towards elected officials, participation in political dialogue, and intention to engage in civic action (Flanagan, Syversten \& Stout, 2007). In a large-scale study of California high school students, Kahne, Feezel and Lee (2011) explored the relationship between digital media literacy education and online political participation, examining whether digital media literacy education could serve to "bridge the gap" between media usage and political activism. Digital media literacy education was found to be associated with an increase in 
politically-driven online activities. These researchers also found that media literacy education is associated with higher levels of online exposure to diverse perspectives.

The precise learning outcomes of digital media literacy may depend upon what instructional aims goals and practices are used. Some programs emphasize leadership, creativity, and collaboration, for example, while others emphasize the acquisition of factual knowledge, research skills, or critical analysis. In a study of college students, Mihailidis (2008) found that while media literacy education did strengthen students' analytical skills, it did not necessarily embolden them as citizens who understand media's essential role in civil society. In fact, media literate students were more likely to adopt a cynical attitude toward media, particularly with regard to media credibility and relevance. Mihailidis acknowledged that many media literacy educators simply assume that teaching critical analysis skills will lead to healthy engagement with media and participation in democratic practices. He writes,

Without defining the experiential outcomes of media literacy and working to ensure their transfer... [there is a] risk of succeeding in teaching students to be critical without teaching them how to become engaged. Students should be constantly reminded of the larger reasons for skill attainment - the awareness of media's role in society and the personal engagement between individuals and media that allow for informed viewing. (Mihaildis, 2008, p. 146-147)

Building on this work, we examine research questions in this study that explore the relationship between students' media use habits in the home; video production learning experiences in and out of school; life skills including leadership, intellectual curiosity, and collaboration; attitudes towards school and media; and civic engagement. We ask: 
RQ3: Is there a relationship between video production skills, media literacy, attitudes towards media, and civic engagement?

\section{RESEARCH METHODS}

This pilot study surveyed a convenience sample from an ethnically diverse high school where students were completing one of the three video production courses offered during the fall of 2011. As part of their coursework, students completed an online questionnaire during class time within ten days of the end of the semester. Students had 50 minutes to complete the survey.

\section{Sample, Background and Context}

Sample. Students came from a middle-class, ethnically diverse community: Located in suburban Detroit, Michigan, Thurston High School has 1081 students including 61\% African American, 33\% Caucasian, 3\% Hispanic/Latino, 1\% Asian/Pacific Islander and 2\% two or more races (NCES, 2010). In a community of about 50,000 residents, most students plan on continuing education after graduation: many will start at a two-year school and then transfer to a four-year school, and some join the military. Annual median income in 2009 was reported at $\$ 47,500$ (U.S. Census, 2010).

Instructional Context. The instructor, Kara Clayton, is a veteran high school video production teacher who has worked at Thurston High School since 1996. She received the National Council of Teachers of English (NCTE) Media Literacy Award and was named Michigan's Visual and Media Arts Teacher of the Year in 2012. Active in the media literacy community, Clayton was instrumental in developing a comprehensive media studies program at Thurston High School, which has grown from one section of a 
single course in 1996 to the current robust media production and analysis program, which includes multiple courses and teachers. The high school offers two Media Studies courses. "Media Analysis" is open to students in Grades 9 through 12. Students who pass this course are eligible to enroll in "Media Production," which is the second course in the Media Studies elective track. These courses meet daily for 50 minutes (Clayton, 2012).

\section{Measures Used in the Study}

Measures included student self-report of technical and non-technical multimedia production skills, in-class participation in a variety of multimedia production activities, media attitudes (including cynicism, perception of media self-interest, and positive intent and value of news in society), intention towards civic engagement, and media literacy.

Vocational interest in news media careers included three items: I am interested in pursuing a career in journalism, I plan on studying media and journalism in college, and I would like to work for a news organization. Respondents were asked to indicate their level of agreement using a five point scale: strongly disagree, disagree, neutral, agree, and strongly agree. Cronbach's alpha for these items was .85. Scores were summed to form an index which ranged from 5 to $15(M=8.5, S D=3.4)$.

Technical and non-technical production skills. Subjects were asked to selfreport their production skills. Production skills included twelve items. Factor analysis identified two sub-scales, technical skills and non-technical skills. Technical production skills consisted of six items: I have the skills I need to make a professional news video; I can use a video camera to film news reports; I am comfortable using a handheld camera to film video; I can fix audio and video quality; I can plan, direct and produce video; and 
I can do substantial video editing. Respondents used a five point scale: Not at all like me, not much like me, somewhat like me, mostly like me and very much like me. Cronbach's alpha for these items was .91 . Scores were summed to form an additive index which ranged from 0 to $30(M=20.4, S D=6.5)$. Non-technical production skills also consisted of six items: I know how to conduct interviews to gather information, I can compare fact and opinion, I know how to develop a news story pitch, I use the Internet to gather reliable information, I am confident interviewing a stranger, and I know how to present myself on camera. Respondents used a five point scale: Not at all like me, not much like me, somewhat like me, mostly like me and very much like me. Cronbach's alpha for these items was .86 . Scores were summed to form an index which ranged from 0 to 30 ( $M$ $=21.5, S D=5.3)$. See Table 1 for mean and standard deviations of technical and nontechnical production skills.

Place Table 1 about here

Media production activities. While the previous variable asked students to report their competence in various non-technical and technical production skills, we constructed another item that asked students to report on which in-class activities they actually engaged in during the semester. This item is a more granular self-report of actual in-classroom participation which addresses the differential involvement in coursework that is common in multimedia production courses. After consulting with the teacher, we composed a list of 12 different media production activities that occurred during the class, divided into three types of experience: Production 1 (pre-production), Production 2 
(production), and Production 3 (post-production). These variables were dichotomous, not scaled; students simply checked the activities that they had done in the class. Production 1 included four items: learned about the drop-out crisis in America, learned about how TV news in created, learned about the practice of journalism, and compared fact and opinion in different types of stories. Scores were summed to form an additive index which ranged from 0 to $4(M=2.4, S D=1.7)$. Production 2 included nine items: conducted interviews to gather information, learned how to develop a news story pitch, used the Internet to gather information, discussed different points of view about social and political issues, used a video camera to film, wrote a script, performed in front of the camera, and worked behind the scenes in different roles on a news production team. Scores were summed to form an additive index which ranged from 0 to $9(M=3.2, S D=$ 2.0). Production 3 included four items: logged footage, edited images and sounds to create video reports, posted videos online, and edited our reports in response to feedback from others. Scores were summed to form an additive index which ranged from 0 to 4 ( $M$ $=1.6, S D=1.4)$. To make these items comparable with each other, we then converted the scores into an index between 0 and 1 , so that the scores represent a percentage of the total items for each subscale. See Table 2 for summary data of in-class production experiences.

Place Table 2 about here

Civic engagement. We defined civic engagement as intention to participate in individual acts of agency in relation to the public sphere. Respondents were asked to 
indicate their level of agreement using a five point scale: strongly disagree, disagree, neutral, agree, and strongly agree. Items included: I would sign an online petition or write a comment on a website about an issue I care about; I will contact a newspaper, radio or TV talk show to express my opinion about an issue I care about; I will write an opinion letter to a newspaper on an issue I care about; I will blog about an issue I care about. Cronbach's alpha for these items was .83. Scores were summed to form an additive index which ranged from 4 to $20(M=12.6, S D=3.6)$.

Media literacy included six items based on the core concepts and key principles of media literacy education, as identified by the National Association for Media Literacy Education (NAMLE, 2007). Respondents were asked to indicate their level of agreement using a five point scales: strongly disagree, disagree, neutral, agree and strongly agree. Items included: people should understand how decisions are made about the news media that we watch, see and read; people should learn to recognize political bias in the news; people should understand how news organizations make money; when I watch a news story, I know that people may have different opinions about it than me; people interpret news reports based on their own life experience; and everyone interprets news stories based on what they already know and believe. Cronbach's alpha for these items was .86 . Scores were summed to form an additive index which ranged from 5 to $30(M=23.4, S D$ =3.9). Table 3 displays the items, means, and standard deviations for the intention to participate in civic engagement and the media literacy attitude scale.

Place Table 3 about here 
Media attitudes. Because the scholarly literature on media literacy had indicated that media literacy education may increase cynicism, we also measured various dimensions of subjects' attitudes toward the news media. We included three subscales including (a) media cynicism, (b) perception of media self-interest, and (c) perception of positive intent and value of news. Respondents were asked to indicate their level of agreement using a five-point response scale: strongly disagree, disagree, neutral, agree, and strongly agree. Media cynicism included three items: I don't really care about news or current events, news and current events don't really affect me, and journalism doesn't make a difference one way or the other. Cronbach's alpha for these items was .84. Scores were summed to form an index which ranged from 5 to $15(M=7.1, S D=2.6)$. Perception of media self-interest included four items: most news companies will say anything to make a profit, the news media doesn't care about ordinary people, journalists will distort the truth in order to grow audiences, and most news is just an advertisement for large corporations. Cronbach's alpha for these items was .77. Scores were summed to form an index which ranged from 5 to $15(M=12.8, S D=3.3)$. Perception of positive intent and value of news included three items: news reporters try to cover issues that are important to society, journalists usually make a substantial effort to be accurate, and news reports help people make decisions about their society. Cronbach's alpha for these items was .67. Scores were summed to form an index which ranged from 5 to $15(M=10.3, S D$ $=2.3$ ). Table 4 shows this data.

Place Table 4 about here 


\section{RESULTS}

This study explores the relationship between civic engagement and the various multimedia instructional practices used in a high school video production course with a single-school convenience sample and an ethnically diverse population of students. Our intent was to explore how in-school multimedia production experiences may contribute to the development of media literacy and civic engagement competencies. We analyzed the data in three stages: first, we compiled descriptive statistics, then we used factor analysis to determine the reliability and validity of construct variables, and then we performed a regression analysis to determine relationships between variables. Three major findings emerged.

Students self-report more non-technical than technical skills. Our first research question asked student to assess their competence on range of skills and competencies associated with the video production process. Findings reveal that students in this sample reported more non-technical production skills $(\mathrm{M}=21.5, \mathrm{SD}=5.3)$ than technical skills $(M=20.4, S D=6.5)$. Comparison of means reveals this to be a statistically significant finding, $\mathrm{t}=36.48, \mathrm{df}=81, \mathrm{p} .<.001$. Students feel more competent with non-technical skills like using the Internet to gather information $(M=4.10, S D=.96)$, comparing fact and opinion $(\mathrm{M}=3.90, \mathrm{SD}=1.0)$, and presenting themselves on camera $(\mathrm{M}=3.92, \mathrm{SD}=$ 1.1). Students are less comfortable with the persuasive skill of developing a news story pitch $(\mathrm{M}=2.63, \mathrm{SD}=1.2)$. As shown on Table 1 , students report relatively high levels of 
competence in self-reporting their ability to use a handheld camera $(\mathrm{M}=4.08, \mathrm{SD}=1.0)$ and using a video camera to film news reports $(\mathrm{M}=3.50, \mathrm{SD}=1.3)$.

\section{Students have different types of learning experiences with multimedia}

production even while enrolled in the same production classes. Because high school video production students work in collaborative groups, there are inevitably some differences between individuals in their choice of in-class activities. Some students may prefer some activities and dislike or avoid others. We asked students to report which inclass media production activities in which they had actually participated, checking activities from a list. We grouped these activities into three categories: Production 1 (preproduction) activities, Production 2 (production) activities, and Production 3 (postproduction) activities. Students, on average, indicated that they engaged in fewer than half of the Production 1 (40\%) and Production 3 (40\%) activities which were listed. Students seem to prefer production activities over pre-production or post-production activities, as they indicated that they engaged in about half (53\%) of the Production 2 activities. Comparison of means revealed that these differences were statistically significant: $\mathrm{t}=13.54, \mathrm{df}=83, \mathrm{p}<.001$.

Even though students were enrolled in the same multimedia production classes, they do not all have the same learning experiences. For example, the most common Production 1 activities were using the Internet to gather information (84\%) and learning how TV news is created (70\%). The least common Production 1 skills involved the exploration of contemporary social issues, including learning about the drop-out crisis (14\%) and discussing different points of view about social and political issues $(28 \%)$. The most common Production 2 activities were writing a script (83\%), using a video camera 
to film $(69 \%)$, and performing in front of the camera $(69 \%)$. The least common

Production 2 activity was learning how to develop a news story pitch (35\%). In this particular class, students may not have had the opportunity to understand social and political issues and gain background knowledge through interactive discussion activities in order to relay the message to a target audience. For Production 3 experiences, posting videos online (59\%) was most common. The least common activity was editing a report in response to feedback from others $(32 \%)$. Such differences suggest that researchers must use highly granular assessments of the various kinds of multimedia production activities that students complete in order to examine the impact of these practices on learning outcomes.

Students who are most engaged in production activities have the highest level of interest in media and journalism careers. In RQ 2, we asked whether active participation in video production courses is associated with pre-professional vocational interest in media careers. A correlational analysis revealed that, not surprisingly, students who have high levels of participation in the in-class production activities have high levels of interests in pursuing a career in journalism $(\mathrm{r}=.31, \mathrm{p}<.001)$.

\section{Civic engagement is associated with positive attitudes about the news, media}

literacy competencies, and in-class pre-production experience. In RQ3, we conducted a stepwise regression analysis with civic engagement as the dependent variable and media literacy, in-class experience with pre-production, production, and post-production, media cynicism, perception of self-interest in news, positive value of the news, and a vocational interest in journalism as the independent variables. 
Place Table 5 about here

Stepwise regression identified three variables which were statistically significant $(\mathrm{F}=12.58, \mathrm{p}<.001)$, explaining approximately $35 \%$ of the variance of civic engagement $\left(\mathrm{R}=.598, \mathrm{R}_{2}=.35\right.$, Adjusted $\left.\mathrm{R}_{2}=.33\right)$. Civic engagement was predicted by (a) positive attitudes towards the news, (b) media literacy, and (c) in-class experience with preproduction activities, as shown on Table 5. Positive attitudes about the news received the strongest weight in the model, followed by media literacy and in-class experience with video production. Inspection of the structure coefficients suggests that positive attitudes towards news, media literacy, and in-class production experience are strong indicators of civic engagement.

\section{DISCUSSION}

Civic engagement is inherently an act of optimism about human nature, social organization, and the future. This study found that the best predictor of civic engagement among adolescents enrolled in a video production class is a positive attitude about the news, followed by media literacy competencies, followed by in-class video production experience. The knowledge, skills and competencies activated in a video production class are undoubtedly perceived by many students as highly relevant to active participation in an increasingly digitally-centric world. By connecting classroom and culture, students increase skills of leadership, intellectual curiosity and collaboration.

Given the substantive contribution of pre-production activities to support civic engagement, it was disappointing to see that many students did not have substantial 
experience with pre-production in their media production classes. It's likely that, with a diverse group of young people, only a small group of students are active in preproduction activities that involve learning about how TV news is constructed, the practice of journalism, and researching and framing up social issues of relevance to the community. This fits with the literature which has found that students in video production courses acquire specialty expertise in certain skill sets (Reilly, 1999). Teachers of video production courses might consider providing more explicit instruction in pre-production to help students learn information gathering skills, the practice of broadcast journalism, and the nature of evaluating informational claims through comparison/contrast.

Evidence from this study shows that students with exposure to these types of inclassroom activities are more civically engaged than other students who may only experience in-classroom learning experiences in production activities such as handling the camera or performing in front of the camera. Pre-production in-classroom learning activities also seem to contribute more towards civic engagement than post-production activities such as video editing and sound mixing.

Data from this study also helps address concerns by Mihailidis (2008) and others who are troubled that the development of media literacy competencies may be associated with increased cynicism, alienation, and disengagement from the political process. This study found that the most media-literate students have more positive but nuanced perspectives on the role of journalism and society. For example, they recognize that news reporters try to cover issues that are important to society and make a substantial effort to be accurate. They recognize the value of information and are aware of how news helps people make decisions about their society. At the same time, they also understand the 
value of knowing how decisions are made about news media messages. They think it's important to recognize political bias in the news and understand how news organizations make money. And they are aware that when they watch a news story, other people may have different opinions about it.

Are these important conceptual understandings the result of getting plenty handson video production experience in a high school classroom? Or do students with these attitudes and beliefs find themselves attracted to participate in a large number of in-class video production activities? Our study found a robust correlation between active participation in video production experience, media literacy, positive attitudes about the news, and civic engagement. But this pilot study design did not permit us to address the chicken-or-egg question to determine causal influence; fortunately, our future work in program evaluation, which will use a pre-post design with a much larger sample of students and high school programs, should enable us to test this more directly.

One issue associated with students' self-reported in-classroom activity in a high school video production gives us pause and introduces a new research question for future scholars to consider. Given that this data was collected at the end of the semester, it is noteworthy that nearly one-third of the students indicated that they did not participate in in-class production activities. More research is needed to understand uneven participation in the context of high school video production coursework. Uneven levels of participation could negatively impact the ability to measure program effectiveness. It's possible that uneven participation in video production courses reflect administrative and enrollment strategies within individual high schools. For example, in some schools, guidance counselors place low-performing students who are the verge of dropping out in video 
production courses. Student absences, failure to participate, and attitude problems may explain some of these results.

We note another caution about research designed to measure the impact of high school video production classes is raised by this pilot study. Because students generally select video production courses as electives in high school, it has been difficult to conduct evaluation research that demonstrates the program effectiveness in naturalistic high school environments because of non-random assignment to classes and the problem of selection bias. For example, the Newspaper Association of American Foundation (2008) conducted research to show that student journalists earn better high school grades, perform at higher levels on college entrance exams, and receive higher grades in college writing and grammar courses than students who lack that experience. But it is likely that students choose to enroll in these programs are different than those who choose not to enroll.

Another avenue to consider in future research is students' news consumption patterns. In addition to media literacy competencies and in-class video production experience, the most civically-engaged adolescents in this study demonstrated a positive attitude about the news. Our future research will closely examine student news consumption in addition to attitudes and classroom experience. To build robust levels of community engagement in young people, it is likely that use of news media must be paired with programs that activate students' understanding of the constructed nature of media messages as well as programs and experiences that demonstrate the positive values of news media on individuals and society. 


\section{References}

Arke, E.T. \& Primack, B. (2009). Quantifying media literacy: Development, reliability, and validity of a new measure. Educational Media International, 46(1), 53-65.

Bachman, J. G., Johnston, L. D., \& O'Malley, P. M. (2008). Monitoring the future: Questionnaire responses from the nation's high school seniors, 2006. Ann Arbor, MI: Institute for Social Research.

Banks J. A. (2001). Citizenship education and diversity: implications for teacher education. Journal of Teacher Education 52(1): 5-16. DOI:

$10.1177 / 0022487101052001002$

Bennett, L., Wells, C. \& Freelon, D. (2011). Communicating civic engagement: Contrasting models of citizenship in the youth web sphere. Journal of Communication 61(5), 835 - 856. DOI: 10.1111/j.1460-2466.2011.01588.x

Clayton, K. (2012). Thurston High School Media Program. Retrieved from https://www.facebook.com/groups/502830399745312/

Duran, R.L., Yousman, B., Walsh, K.M., \& Longshore, M.A. (2008). Holistic media education: An assessment of the effectiveness of a college course in media literacy. Communications Quarterly, 56(1), 49-68.

Flanagan, C.A., Syversten, A.K., \& Stout, M.D. (2007). Civic measurement models: Tapping adolescents' civic engagement, CIRCLE Working Papers. Retrieved from www.civicyouth.org/PopUps/WorkingPapers/WP55Flannagan.pdf

Goble, D. (2012). Don Goble, Broadcast Technology and Film. Ladue High School. Retrieved from 
http://www.ladue.k12.mo.us/lhwhs/teacher_websites/dgoble/don_iweb/Site/Home . html

Hallam, M. (2010). WUJW still going strong after 40 year. Urban Pioneer. Retrieved from http://2010urbanpioneer.columbiamissourian.com/2010/07/mujw-stillgoing-strong-after-40-years-of-scholastic-journalism/

Hobbs, R. (2011). Digital and media literacy: Connecting classroom and culture. Thousand Oaks, CA: Corwin/Sage.

Hocutt, M. Stanford, R. Wright V. and Raines, M. (2001). How students learn new technologies. Electronic Journal for the Integration of New Technology in Education 1 (2). Retrieved from http://ejite.isu.edu/Volume1No2/Hocutt.htm

Hull, G., \& James, M. (2007). Geographies of hope: A study of urban landscapes and a university-community collaborative. In Peggy O'Neill (Ed.), Blurring boundaries: Developing writers, researchers, and teachers: A tribute to William L. Smith (pp. 250-89). Cresskill, NJ: Hampton Press.

Ito, M. \& Salen, K. (2012). The essence of connecte learning environments. Connected Learning. Retrieved from http://connectedlearning.tv/mimi-ito-katie-salen$\underline{\text { essence-connected-learning-environments }}$

Kahne, J., Feezel, J.T. \& Lee, N. (2010). Digital media literacy education and online civic and political participation. DMLCentral Working Papers, Youth \& Participatory Politics. Retrieved from http://dmlcentral.net/resources/4429

Martens, A. \& Gainous, J. (2012). Civic education and democratic capacity: How do teachers teach and what works? Social Science Quarterly doi: 10.1111/j.15406237.2012.00864. 
Martens, H. \& Hobbs, R. (in press). How media literacy supports engagement in a digital age. Atlantic Journal of Communication.

Masterman, L. (1985). Teaching the media. London: Polity Press.

Mihailidis, P. (2008). Beyond cynicism: How media literacy can make students more engaged citizens (Doctoral dissertation). Retrieved from www.drum.lib.umd.edu/bitstream/1903/8301/1/umi-umd-5277.pdf

Miller, S.M. (2010). Reframing multimodal composing for student learning: Lessons on purpose from the Buffalo DV project. Contemporary Issues in Technology and Teacher Education, 10(2). Retrieved from http://www.citejournal.org/vol10/iss2/maintoc.cfm

Murphy, J. Hull, T. \& Walker, A. (1987). Academic drift and curriculum debris: Analysis of high school course taking patterns and its implications for local policy makers. Journal of Curriculum Studies 19(4), 341 - 360.

National Association of Media Literacy Education, (2007). Core principles of media literacy education in the United States. Retrieved from http://namle.net/2009/09/NAMLE-CPMLE-w-questions2.pdf

National Council on the Social Studies (2009) Position statement on media literacy. Retrieved from http://www.socialstudies.org/positions/medialiteracy Newspaper Association of America Foundation (2008). High school journalism matters. Retrieved from http://www.americanpressinstitute.org/research/foundation/ $\underline{\text { Student-Journalism/High-School-Journalism-Matters.aspx }}$

Norton, P., \& Hathaway, D. (2010). Video production as an instructional strategy: Content Learning and teacher practice. Contemporary Issues in Technology and 
Teacher Education, 10(1). Retrieved from http://www.citejournal.org/vol10/iss1/currentpractice/article2.cfm

Pasek, J., Kenski, K., Romer, D., \& Jamieson, K. (2006). America’s youth and community engagement. Communication Research, 33(3), 115-135.

Pinkham, C., White, S.E., \& Silvernail, D.L. (2008). 21st century teaching and learning: An assessment of student website evaluation skills. Center for Education Policy, Applied Research, and Evaluation: University of Southern Maine and Sanford Junior High School. Retrieved from www.maine.gov/mlti/resources/21st_Century _Teaching_and_Learning_Website.pdf

Reilly, B. (1994). Composing with Images: A Study of High School Video Producers. Educational Multimedia and Hypermedia, 1994. Proceedings of ED-MEDIA 94-World Conference on Educational Multimedia and Hypermedia. Vancouver, British Columbia, Canada. ERIC ED388289.

$21^{\text {st }}$ Century Information Fluency (2012). Common Core State Standards mapped to the Information Fluency Model. Retrieved June 30, 2013 from https://21cif.com/resources/difcore/ccss-dif.html 
Table 1

Multimedia Production Skills of High School Students

Technical Skills

I have the skills I need to make a professional news video.

I can use a video camera to film news reports.

I am comfortable using a handheld camera to film video.

I can fix audio and video quality.

I can plan, direct and produce video.

I can do substantial video editing.

Subtotal
Mean

\subsection{6}

3.5

4.08

3.14

3.31

3.11

20.4
SD Range

$1-5$

1.2

1.3

$1-5$

1.0

1 - 5

1.3

$1-5$

1.4

$1-5$

1.4

$1-5$

6.5

$6-30$

Non-Technical Skills

I know how to conduct interviews to gather information.

I can compare fact and opinion.

I know how to develop a news story pitch.

I use the Internet to gather reliable

information.

I am confident interviewing a stranger.

I know how to present myself on camera.

Subtotal
3.3

3.9

2.63

4.1

3.62

3.92

21.5
1.1

1.0

1.2

.96

1.3

1.1

5.3
$1-5$

$1-5$

1- 5

$1-5$

$1-5$

$1-5$

$6-30$ 
Table 2.

Students' Self-Reported Multimedia

In-Class Production Experiences

\begin{tabular}{|c|c|c|}
\hline Production 1 & $\begin{array}{c}\text { Percent } \\
\mathbf{4 0 \%}\end{array}$ & $\begin{array}{l}\mathrm{N} \\
\mathbf{8 5}\end{array}$ \\
\hline $\begin{array}{l}\text { Learned about the drop-out crisis in } \\
\text { America }\end{array}$ & $14 \%$ & 11 \\
\hline Learned about how TV news is created & $70 \%$ & 54 \\
\hline Learned about the practice of journalism & $31 \%$ & 24 \\
\hline $\begin{array}{l}\text { Compared fact and opinion in different } \\
\text { types of news articles }\end{array}$ & $40 \%$ & 31 \\
\hline
\end{tabular}

Production 2

$52 \%$

85

Conducted interviews to gather

information

$47 \%$

36

Learned how to develop a news story pitch

$35 \%$

27

Used the Internet to gather information

$84 \%$

65

Discussed different points of view about social and political issues

$29 \% \quad 22$

Used a video camera to film

$69 \% \quad 53$

Wrote a script

$83 \% \quad 64$

Performed in front of the camera

$69 \%$

Worked behind the scenes in different

roles on a news production team

$48 \%$

37

Production 3

$40 \%$

85

Logged footage

$40 \%$

31

Edited images and sounds to create video reports

$47 \% \quad 36$

Posted videos online

$60 \%$

46

Edited our reports in response to feedback from others

$33 \%$

25 
Table 3

Civic Engagement and Media Literacy Attitudes

\begin{tabular}{|c|c|c|c|c|}
\hline Civic Engagement & Mean & SD & $\mathrm{N}$ & Range \\
\hline $\begin{array}{l}\text { I would sign an online petition or write a } \\
\text { comment on a website about an issue I care } \\
\text { about. }\end{array}$ & $3.5(1.1)$ & 1.1 & 79 & $1-5$ \\
\hline $\begin{array}{l}\text { I will contact a newspaper, radio or TV talk } \\
\text { show to express my opinion on an issue. }\end{array}$ & 3.1 & 1.2 & 78 & $1-5$ \\
\hline $\begin{array}{l}\text { I will write an opinion letter to a newspaper } \\
\text { on an issue I care about. }\end{array}$ & 2.8 & 1.1 & 78 & $1-5$ \\
\hline I will blog about an issue I care about. & 3.2 & 1.1 & 79 & $1-5$ \\
\hline Subtotal & 12.6 & 3.6 & 77 & $4-20$ \\
\hline \multicolumn{5}{|l|}{ Media Literacy } \\
\hline $\begin{array}{l}\text { People should understand how decisions are } \\
\text { made about the news media that we watch, } \\
\text { see and read. }\end{array}$ & 1.95 & 0.9 & 85 & $1-5$ \\
\hline $\begin{array}{l}\text { People should learn to recognize political } \\
\text { bias in the news. }\end{array}$ & 2.17 & 0.9 & 85 & $1-5$ \\
\hline $\begin{array}{l}\text { People should understand how news } \\
\text { organizations make money. }\end{array}$ & 2.44 & 0.94 & 85 & $1-5$ \\
\hline $\begin{array}{l}\text { When I watch a news story, I know that } \\
\text { people may have different opinions about it } \\
\text { than me. }\end{array}$ & 1.89 & 0.89 & 85 & $1-5$ \\
\hline $\begin{array}{l}\text { People interpret news reports based on their } \\
\text { own life experiences. }\end{array}$ & 2.05 & 0.78 & 85 & $1-5$ \\
\hline $\begin{array}{l}\text { Everyone interprets news stories based on } \\
\text { what they already know and believe. }\end{array}$ & 2.1 & 0.84 & 85 & $1-5$ \\
\hline Subtotal & 23.4 & 3.9 & 85 & $6-30$ \\
\hline
\end{tabular}


Table 4

Media Attitudes

\begin{tabular}{llll} 
& $\underline{\text { Mean }}$ & $\underline{\text { SD }}$ & $\underline{\text { N }}$ \\
\cline { 2 - 4 } Media Cynicism & 3.49 & 1.02 & 79 \\
\hline I don't really care about current events & 3.73 & 0.97 & 79 \\
$\begin{array}{l}\text { News and current events don't really affect me } \\
\text { Journalism doesn't make a difference one way or }\end{array}$ & 3.67 & 0.97 & 78 \\
$\begin{array}{l}\text { the other } \\
\text { Subtotal }\end{array}$ & $\mathbf{7 . 1}$ & $\mathbf{2 . 6}$ & $\mathbf{8 5}$
\end{tabular}

\section{Perception of Media Self-Interest}

Most news companies will say anything to make a profit

$\begin{array}{lll}2.62 & 1.16 & 79 \\ 3.07 & 1.02 & 79 \\ 2.44 & 1.03 & 79 \\ 3.06 & 1.01 & 79 \\ \mathbf{1 2 . 8} & \mathbf{3 . 3} & \mathbf{7 9}\end{array}$

The news media does care about ordinary people Journalists will distort the truth in order to grow audiences

12.8

Perception of Positive Intent and Value of News

\begin{tabular}{llll}
\hline $\begin{array}{l}\text { News reporters try to cover issues that are } \\
\text { important to society }\end{array}$ & 2.63 & 1.05 & 78 \\
$\begin{array}{l}\text { Journalists usually make a substantial effort to be } \\
\text { accurate }\end{array}$ & 2.52 & 0.94 & 78 \\
$\begin{array}{l}\text { News reports help people make decisions about } \\
\text { Society }\end{array}$ & 2.5 & 0.92 & 79 \\
Subtotal & $\mathbf{1 0 . 3}$ & $\mathbf{2 . 3}$ & $\mathbf{8 5}$
\end{tabular}


Table 5

Stepwise Regression: Predictors of Civic Engagement

\begin{tabular}{lcccc}
\hline & Model 1 & & & \\
\cline { 2 - 5 } & $\mathrm{B}$ & $S E$ & $B$ & Sig \\
\hline Intercept & -4.17 & 2.43 & & \\
Positive Value News & 0.47 & 0.16 & 0.30 & 0.005 \\
Media Literacy & 0.25 & 0.08 & 0.30 & 0.004 \\
Pre-Production & 2.82 & 1.83 & 2.16 & 0.03 \\
& & & &
\end{tabular}

$\mathrm{F}=12.58, \mathrm{p}<.001$

Excluded variables: production, post-production, vocational interest, media cynicism, media self-interest 